\title{
KUALITAS HIDUP REMAJA DI KOTAMOBAGU SULAWESI UTARA PADA MASA PANDEMI CORONAVIRUS DISEASE 2019
}

\author{
Irmawaty Buleno", Jeini Ester Nelwan", Joshua Runtuwene ${ }^{3}$, Aaltje Ellen Manampiring ${ }^{3}$, \\ Gustaaf Ratag ${ }^{3}$ \\ ${ }^{1}$ Kantor Kesehatan Pelabuhan Kelas II Manado Kementerian Kesehatan Republik Indonesia \\ ${ }^{2}$ Fakultas Kesehatan Masyarakat Universitas Sam Ratulangi \\ ${ }^{3}$ Fakultas Kedokteran Universitas Sam Ratulangi \\ *Email add: jeini_ester83@unsrat.ac.id
}

Diterima : November 2021, Diterbitkan : Desember 2021

\begin{abstract}
Abstrak
Pendahuluan: Kualitas hidup merupakan suatu ukuran untuk melihat status kesehatan individu secara komprehensif. Kualitas hidup dinilai berdasarkan domain fisik, psikologis, sosial dan lingkungan. Remaja merupakan salah satu populasi yang harus diperhatikan. Tujuan penelitian ini yaitu untuk menganalisis kualitas hidup remaja di Kotamobagu Sulawesi Utara pada masa pandemi Corona Virus Disease 2019 (Covid-19). Metode: Penelitian ini merupakan penelitian kuantitatif. Penelitian ini dilaksanakan di Kotamobagu pada Oktober-November 2021. Responden dalam penelitian ini sebanyak 441 remaja yang merupakan siswa SMP dan SMA. Faktor yang dianalisis yaitu kualitas hidup remaja secara umum dan kualitas hidup berdasarkan dimensi kesehatan fisik, psikologis, hubungan social dan lingkungan. Data yang diperoleh dianalisis secara univariat. Hasil: Hasil penelitian ini menunjukkan bahwa kualitas hidup remaja di Kotamobagu lebih dari $80 \%$ masuk pada kategori sedang dan buruk. Hasil penelitian ini juga menunjukkan skor rataan kualitas hidup remaja berada pada nilai 56,95. Jika dilihat berdasarkan 4 dimensi kualitas hidup menurut WHOQoL yaitu kesehatan fisik, psikologis, hubungan sosial dan lingkungan. Skor rataan untuk dimensi kesehatan fisik sebesar 50,12, dimensi psikologis sebesar 60,89, dimensi hubungan sosial sebesar 51,32 dan dimensi lingkungan sebesar 64,89.
\end{abstract}

Kata kunci: Kualitas hidup; Remaja; Kotamobagu

\begin{abstract}
Introduction: Quality of life is a measure to see an individual's health status comprehensively. Quality of life is assessed based on physical, psychological, social and environmental domains. Adolescents are one of the population that must be considered. The purpose of this study was to analyze the quality of life of adolescents in Kotamobagu, North Sulawesi during the Corona Virus Disease 2019 (Covid-19) pandemic. Method: This is a quantitative research. This research was conducted in Kotamobagu in OctoberNovember 2021. The respondents in this study were 441 teenagers who were junior high and high school students. The factors analyzed are the general quality of life of adolescents and the quality of life based on the dimensions of physical, psychological, social and environmental health. The data obtained were analyzed univariately. Results: The results of this study indicate that the quality of life of adolescents in Kotamobagu is more than $80 \%$ in the moderate and poor categories. The results of this study also showed that the average score of the quality of life for adolescents was 56.95. When viewed based on 4 dimensions of quality of life according to WHOQoL, namely physical, psychological, social and environmental health. The average score for the physical health dimension is 50.12, the psychological dimension is 60.89, the social relationship dimension is 51.32 and the environmental dimension is 64.89.
\end{abstract}

Keywords: Quality of life; Adolescents; Kotamobagu 


\section{PENDAHULUAN}

The Centers for Disease Control and

Prevention (CDC) menyatakan bahwa kualitas hidup merupakan konsep multidimensi yang luas yang biasanya mencakup evaluasi subjektif dari aspek positif dan negatif dari kehidupan. Kesehatan merupakan salah satu domain penting dari kualitas hidup. Selain itu, ada domain lain seperti pekerjaan, perumahan, sekolah, lingkungan. Aspek budaya, nilai, dan spiritualitas juga merupakan domain kunci dari kualitas hidup secara keseluruhan. Hal inilah yang menambah kompleksitas pengukurannya (CDC, 2021).

Kualitas hidup yang berhubungan dengan kesehatan diistilahkan dengan Health Related Quality of Life (HRQoL) merupakan jembatan antara kajian disiplin ilmu sosial, mental, dan medis. Beberapa perubahan kebijakan ini menggaris bawahi kebutuhan untuk mengukur HRQoL dalam rangka melengkapi ukuran awal kesehatan masyarakat seperti morbiditas dan mortalitas. HRQoL terkait dengan penyakit kronis seperti diabetes, kanker payudara, radang sendi, dan hipertensi dan faktor risikonya (indeks massa tubuh, aktivitas fisik, dan status merokok) (CDC, 2021).

Data US News and World Report dalam 2019 Best Countries menunjukkan, kualitas hidup Indonesia berada di peringkat ke-40 dari 80 negara yang disurvei. Skor Indonesia tergolong rendah dibandingkan dengan negara-negara lainnya, yaitu 1,8 dari skala 10. Rendahnya skor ini disebabkan sembilan indikator yang membentuk kualitas hidup hanya memiliki rata-rata sebesar 1,7. Dari sembilan indikator tersebut, terdapat delapan indikator yang memiliki skor di bawah dua. Indikator terendah terdapat pada sistem kesehatan dan pendidikan dengan skor masing-masing 0,1 dan 0,3. Sementara itu, peringkat terendah selanjutnya terdapat pada stabilitas ekonomi dengan skor 0,4. Stabilitas politik menyusul dengan skor sebesar 0,6. Di sisi lain, terdapat satu indikator yang memiliki skor mendekati sempurna. Hal ini dapat dilihat dari indikator keterjangkauan yang mencapai skor 9,6 (Jayani 2021).

Data kualitas hidup masyarakat di Indonesia bisa dilihat juga berdasarkan nilai indeks pembangunan manusia (IPM). Menurut Badan Pusat Statistik (BPS), IPM mengukur kualitas hidup manusia yang dilihat dari kualitas kesehatan, pendidikan dan pengeluaran per kapita per tahun. IPM mengukur capaian pembangunan manusia berbasis sejumlah komponen dasar kualitas hidup. Sebagai ukuran kualitas hidup, IPM dibangun melalui pendekatan tiga dimensi dasar. Dimensi tersebut mencakup umur panjang dan sehat; pengetahuan, dan kehidupan yang layak. Ketiga dimensi tersebut memiliki pengertian sangat luas karena terkait banyak faktor. Untuk mengukur dimensi kesehatan, digunakan angka harapan hidup waktu lahir (BPS 2021).

World Health Organization (WHO) menyatakan bahwa masa remaja merupakan periode pertumbuhan dan perkembangan manusia yang terjadi setelah masa kanak kanak dan sebelum masa dewasa, yaitu dari usia 10 sampai 19 tahun (WHO 2021). Kementerian Kesehatan Republik Indonesia (Kemenkes RI) menyatakan bahwa di Indonesia, jumlah kelompok usia 10-19 tahun menurut sensus penduduk 2010 berjumlah 43,5 juta jiwa atau sekitar $18 \%$ dari total jumlah penduduk. Remaja yang sehat tidak hanya dilihat dari keadaan fisiknya saja, tetapi juga kondisi mental dan sosialnya. Apabila kondisi fisik, sosial dan mentalnya telah baik, maka akan tercipta kualitas hidup yang baik (Kemenkes RI 2015). Haryono \& Kurniasari (2018) menyatakan bahwa prevalensi kualitas hidup yang rendah pada remaja di Indonesia sebesar $7 \%$.

Model kontekstual HRQoL terdiri dari dua tingkat yaitu makro dan mikro. Tingkat makro (sistemik) mencakup faktor- 
faktor di luar individu yang mempengaruhi fungsinya dan proses pemulihannya. Faktor tingkat makro yang paling menonjol yaitu faktor sosial ekonomi, seperti status sosial ekonomi, beban hidup, dan dukungan sosial; budaya, seperti kebangsaan, budaya, spiritualitas, dan sikap hidup. Tingkat mikro (individu) termasuk karakteristik individu yang mempengaruhi fungsinya dan proses pemulihannya (usia, jenis kelamin, status sosial ekonomi), terkait dengan perawatan medis (kualitas dan akses perawatan medis), perilaku (kualitas tidur, merokok, konsumsi alkohol) dan lainnya (Sosnowski et al 2017).

Hasil observasi lapangan ditemukan bahwa pengukuran kualitas hidup remaja di Kotamobagu belum pernah dilakukan. Selain itu, ditemukan masalah pada kualitas hidup khususnya kesehatan fisik, hubungan social dan psikologis. Tujuan penelitian ini yaitu untuk menggambarkan kualitas hidup remaja di Kotamobagu pada masa pandemic Coronavirus Disease 2019.

\section{METODE PENELITIAN}

Penelitian ini merupakan penelitian deskriptif. Penelitian ini dilaksanakan di kota Kotamobagu pada Oktober-November 2021. Jumlah sampel minimal dihitung menggunakan rumus Lemeshow dan diperoleh minimal 221 responden. Responden yang digunakan penelitian ini yaitu sebanyak 441 remaja yang bersekolah SMP dan SMA. Variabel penelitian ini yaitu kualitas hidup. Kualitas hidup diukur menggunakan kuesioner WHOQoL-Bref. Instrumen penelitian ini yaitu kuesioner yang telah diuji validitas dengan nilai > 0,6 dan reliabilitas dengan nilai $>0,8$. Data penelitian ini diperoleh melalui wawancara. Data yang diperoleh dianalisis secara univariat. Data disajikan dalam tabel dan narasi.

\section{HASIL DAN PEMBAHASAN}

Analisis univariat menjelaskan distribusi kategori kualitas hidup dan 4 dimensi kualitas hidup. Hasil analisis dapat dilihat pada Tabel 1.

Tabel 1. Hasil analisis univariat

\begin{tabular}{|c|c|c|}
\hline \multicolumn{2}{|c|}{ Variabel penelitian } & $\%$ \\
\hline \multirow{4}{*}{ Kualitas hidup } & Buruk & 3.6 \\
\hline & Sedang & 78.0 \\
\hline & Baik & 18.4 \\
\hline & Total & $441 \quad 100.0$ \\
\hline \multirow{4}{*}{$\begin{array}{l}\text { Skor kualitas } \\
\text { hidup }\end{array}$} & Min & 13 \\
\hline & Maks & 88 \\
\hline & Rataan & 56,95 \\
\hline & SD & 12,481 \\
\hline \multirow{4}{*}{$\begin{array}{l}\text { Skor kualitas } \\
\text { hidup dimensi } \\
\text { kesehatan fisik }\end{array}$} & Min & 6 \\
\hline & Maks & 94 \\
\hline & Rataan & 50,12 \\
\hline & SD & 13,743 \\
\hline \multirow{4}{*}{$\begin{array}{l}\text { Skor kualitas } \\
\text { hidup dimensi } \\
\text { psikologis }\end{array}$} & Min & 19 \\
\hline & Maks & 94 \\
\hline & Rataan & 60,89 \\
\hline & SD & 15,266 \\
\hline \multirow{4}{*}{$\begin{array}{c}\text { Skor kualitas } \\
\text { hidup dimensi } \\
\text { hubungan sosial }\end{array}$} & Min & 0 \\
\hline & Maks & 100 \\
\hline & Rataan & 51,32 \\
\hline & SD & 17,100 \\
\hline \multirow{4}{*}{$\begin{array}{l}\text { Skor kualitas } \\
\text { hidup dimensi } \\
\text { hubungan } \\
\text { lingkungan }\end{array}$} & Min & 13 \\
\hline & Maks & 100 \\
\hline & Rataan & 64,89 \\
\hline & SD & 16,384 \\
\hline
\end{tabular}

Hasil penelitian ini menunjukkan bahwa kualitas hidup remaja di Kotamobagu lebih dari $80 \%$ masuk pada kategori sedang dan buruk. Hal ini berarti sebagian besar remaja di Kotamobagu bermasalah pada kualitas hidupnya. Pengukuran kualitas hidup remaja menggunakan kuesioner WHOQoLBref. Kuesioner ini dipilih untuk digunakan karena biasa dilakukan pada populasi umum dan mengukur kualitas hidup yang berhubungan dengan kesehatan. Health Related Quality of Life (HRQoL) akan membantu memantau kemajuan dalam mencapai tujuan kesehatan bangsa. Analisis data surveilans HRQoL dapat mengidentifikasi subkelompok dengan persepsi kesehatan yang relatif buruk dan menjadi dasar penentuan intervensi untuk 
memperbaiki keadaan masyarakat dan mencegah dampak yang lebih serius. Interpretasi dan publikasi data ini dapat membantu mengidentifikasi kebutuhan akan kebijakan dan undang-undang kesehatan, membantu mengalokasikan sumber daya berdasarkan kebutuhan yang tidak terpenuhi, memandu pengembangan rencana strategis, dan memantau efektivitas intervensi masyarakat luas (CDC, 2021).

Indeks Pembangunan Manusia (IPM) Indonesia terus mengalami kemajuan selama periode 2010 hingga 2018. IPM Indonesia meningkat dari 66,53 pada 2010 menjadi 71,39 pada 2018. Selama periode tersebut, IPM Indonesia meningkat dari level sedang menjadi tinggi terhitung mulai tahun 2016. Pada 2018 IPM Indonesia meningkat 0,82\% dibanding 2017 menjadi 71,39. Kualitas kesehatan, pendidikan dan pemenuhan kebutuhan hidup masyarakat Indonesia meningkat (BPS 2021). BPS Sulawesi Utara mencatat IPM Sulawesi Utara pada 2019 mencapai 72,99. Angka ini meningkat sebesar 0,79 poin atau tumbuh 1,09 dari tahun 2018. IPM Sulut terus mengalami peningkatan sejak 2010 sampai 2020. Data IPM Sulut pada 2010 sebesar 67,83 menjadi 72,93 di tahun 2020 (BPS Sulut 2021). Data IPM Kota Kotamobagu pada 2018-2019 tetap stabil pada angka 73 (BPS Kota Kotamobagu 2021).

Hasil penelitian ini juga menunjukkan skor rataan kualitas hidup remaja berada pada nilai 56,95 . Jika dilihat berdasarkan 4 dimensi kualitas hidup menurut WHOQoL yaitu kesehatan fisik, psikologis, hubungan sosial dan lingkungan. Skor rataan untuk dimensi kesehatan fisik sebesar 50,12, dimensi psikologis sebesar 60,89, dimensi hubungan sosial sebesar 51,32 dan dimensi lingkungan sebesar 64,89. Nilai ini menunjukkan bahwa nilai rataan terendah kualitas hidup remaja di Kotamobagu ditemukan pada dimensi kesehatan fisik selanjutnya hubungan sosial.
Nilai ini lebih rendah dari nilai rataan kualitas hidup secara umum yaitu 56,95.

Penelitian dari Porajow (2020) tentang kualitas hidup remaja di kota Manado menunjukkan bahwa nilai kualitas hidup kesehatan fisik remaja Kota Manado sebesar 51,6 poin. Jika dibandingkan dengan nilai kualitas hidup kesehatan fisik remaja di Kota Manado maka nilai kualitas hidup kesehatan fisik remaja di Kotamobagu masih sedikit lebih rendah. Selanjutnya nilai ini jika dibandingkan dengan nilai kualitas hidup kesehatan fisik secara global sebesar 69 maka nilai kualitas hidup kesehatan fisik remaja di Kotamobagu jauh lebih rendah. Nilai kualitas hidup dimensi kesehatan fisik remaja Kotamobagu ini jauh lebih rendah dari remaja di India $(69,7)$ (Awasthi et al. 2012) dan Kuwait, $(70,4)$ (Al-Fayez \& Ohaeri 2011).

Penelitian dari Purba et al (2018) menunjukkan bahwa nilai kualitas hidup kesehatan fisik di Indonesia pada populasi umum sebesar 69,2. Hasil penelitian ini menunjukkan bahwa nilai kualitas hidup dimensi kesehatan fisik juga masih lebih rendah dengan populasi umum. Nilai domain kesehatan fisik dan domain hubungan sosial juga berbeda dengan referensi global. Kedua nilai ini juga lebih rendah dibandingkan dengan remaja-remaja di berbagai tempat lain (Awasthi et al. 2012; Wu et al. 2017; Izutsu et al. 2006). Remaja Kotamobagu memiliki nilai kualitas hidup kesehatan domain lingkungan masih lebih rendah daripada nilai kualitas hidup remaja global walaupun tidak bermakna.

Kualitas hidup secara umum terdiri dari 4 domain yaitu psikologis, kesehatan fisik, sosial, dan lingkungan secara bersamasama menjelaskan $73 \%$ kebahagiaan dan $66 \%$ kesejahteraan secara subjektif. Pada kedua hal sebelumnya, domain psikologis merupakan prediktor terkuat. Faktor lingkungan hanya menjelaskan $14 \%$ dari varian dalam kesejahteraan subjektif dan 
ditemukan tidak signifikan dalam memprediksi kebahagiaan. Medvedev dan Landhuis (2018) menunjukkan bahwa faktor lingkungan tidak muncul sebagai penentu kebahagiaan seseorang. Namun, domain psikologis muncul sebagai prediktor terkuat dari kebahagiaan dan kesejahteraan subjektif yang berbanding terbalik dengan lingkungan dan hubungan sosial. Hubungan sosial menjelaskan paling sedikit perbedaan dalam konstruksi kesejahteraan global yang menunjukkan bahwa mereka mungkin memainkan peran penting tetapi bukan peran utama dalam kesejahteraan individu. Hasil ini konsisten dengan penelitian sebelumnya yang mendukung pendekatan top-down dan menekankan peran kognisi individu dalam kebahagiaan subjektif.

Indikator kualitas hidup dapat dibagi menjadi 4 hal yaitu keterampilan fisik dan motorik, keadaan mental, kondisi sosial dan ekonomi dan persepsi somatik (misalnya, gejala, terutama rasa sakit). Indikator ini dianggap penting khususnya dalam membedakan antara keadaan kesehatan objektif (sebagaimana ditentukan oleh gejala yang diamati) dan pengalaman subyektif pasien mengenai keadaan tersebut dengan menggunakan metode penilaian obyektif dan subyektif. Penilaian objektif mengacu pada metode untuk menentukan situasi aktual seseorang, atau fakta yang terlepas dari pendapat atau perasaan subjektif orang tersebut tentang situasi khusus mereka. Sebaliknya, penilaian subjektif mengacu pada metode penentuan situasi seperti yang dijelaskan oleh pasien, dengan pertimbangan yang cukup dari dimensi emosional dari pengalaman mereka (De Walden-Gałuszko, 2021).

World health organization menyatakan bahwa ada 3 indikator kualitas hidup yaitu fungsi fisik, status mental, dan kemampuan untuk terlibat dalam interaksi sosial normatif (WHO 2012). Fungsi fisik seperti kualitas hasil kerja (mutu hasil kerja), kuantitas hasil kerja (banyaknya/jumlah hasil kerja), efisiensi dalam melaksanakan tugas (kemampuan seseorang dalam melaksanakan tugas secara baik dan tepat yakni tidak membuang waktu, biaya dan tenaga). Status mental seperti disiplin kerja (kemampuan kerja individu untuk secara teratur, bekerja dengan tekun secara terus-menerus berdasarkan aturan-aturan yang ada dan tidak melanggar aturan-aturan tersebut), inisiatif (prakarsa) dan ketelitian (kecermatan). Interaksi sosial normative seperti kejujuran dan kreativitas.

\section{KESIMPULAN DAN SARAN}

Kesimpulan penelitian ini yaitu kualitas hidup remaja di Kotamobagu sebesar 56,95 dengan skor rataan pada dimensi kesehatan fisik 50,12, dimensi psikologis 60,89, dimensi hubungan sosial 51,32 dan dimensi lingkungan 64,89. Berdasarkan hal tersebut maka penelitian selanjutnya dapat melakukan penelitian untuk melihat variabelvariabel yang berpengaruh dengan kualitas hidup seperti faktor spiritualitas, stress, penyakit bawaan dan lainnya.

\section{DAFTAR PUSTAKA}

Al-Fayez GA, Ohaeri JU. 2011. Profile of subjective quality of life and its correlates in a nation-wide sample of high school students in an Arab setting using the WHOQOL-Bref. BMC Psychiatry. 11:71

Awasthi S, Agnihotri K, Chandra H, Singh U, Thakur S. 2012. Assessment of health-related quality of life in schoolgoing adolescents: validation of PedsQL instrument and comparison with WHOQOL-BREF. Natl Med J India. 25(2):74-79

Badan Pusat Statistik. 2021. Indeks Pembangunan Manusia (online) diakses dari https://www.bps.go.id/ pada 1 September 2021 
Badan Pusat Statistik Kota Kotamobagu. 2021. Indeks Pembangunan Manusia (online) diakses dari https://kotamobagukota.bps.go.id/indi cator/26/29/1/ipm-kotakotamobagu.html pada 1 September 2021

Badan Pusat Statistik Sulawesi Utara. 2021. Indeks Pembangunan Manusia (online) diakses dari https://sulut.bps.go.id/pressrelease/202 0/12/15/723/indeks-pembangunanmanusia-provinsi-sulawesi-utaratahun-2020.html pada 1 September 2021

Centers for Disease Control and Prevention. 2021. Health-related quality of life (online) diakses dari https://www.cdc.gov/hrqol/concept.ht m pada 1 September 2021

de Walden-Gałuszko, K., Heyda, A., Wojtkiewicz, M., Mróz, P., Majkowicz, M., \& Wirga, M. (2021). High prevalence of somatic complaints and psychological problems despite high self-declared quality of life in long-term cancer survivors. Oncology in Clinical Practice.

Wu, X. Y., Han, L. H., Zhang, J. H., Luo, S., Hu, J. W., \& Sun, K. (2017). The influence of physical activity, sedentary behavior on health-related quality of life among the general population of children and adolescents: A systematic review. PloS one, 12(11), e0187668.

Haryono, R. H. S., \& Kurniasari, K. (2018). Stres akademis berhubungan dengan kualitas hidup pada remaja. Jurnal Biomedika dan Kesehatan, 1(1), 7584.

Izutsu, K., Arima, K., Abe, Y., Okabe, T., Tomita, Y., Mizukami, S., ... \& Aoyagi, K. (2017). Exercise intervention implemented by trained volunteers improves health-related quality of life among Japanese community-dwelling older females: an intervention study. Journal of physical therapy science, 29(12), 2126-2132.

Jayani, DH. 2021. Bagaimana kualitas hidup di Indonesia (online) diakses dari https://databoks.katadata.co.id/datapub lish/2019/10/09/bagaimana-kualitashidup-di-indonesia pada 1 September 2021

Medvedev, O. N., \& Landhuis, C. E. (2018). Exploring constructs of well-being, happiness and quality of life. PeerJ, 6, e4903

Porajow (2020)

Sosnowski, R., Kulpa, M., Ziętalewicz, U., Wolski, J. K., Nowakowski, R., Bakuła, R., \& Demkow, T. 2017. Basic issues concerning health-related quality of life. Central European journal of urology, 70(2), 206.

World Health Organization. 2012. The World Health Organization Quality of Life (WHOQOL) (online) diakses dari https://www.who.int/publications/i/ite m/WHO-HIS-HSI-Rev.2012.03 pada 1 September 2021

World Health Organization. 2021. Maternal, newborn, child and adolescent health. (online) diakses dari https://www.who.int/maternal_child_a dolescent/topics/adolescence/dev/ pada 1 September 2021 